\title{
When electoral Paradigm meets the research Implications: The Youth Perspective
}

\author{
Jaroslav Mihálik $^{1}$
}

\begin{abstract}
The recent comprehensive research on youth attitudes to democratic governance, political leaders and civic participation has explored several patterns of electoral behaviour of young voters. The major domains of such include support for alternative political platforms, dissatisfaction with the democratic performance, rise of xenophobia and propensity to far-right politics and radical problem solutions. These trends have been, to some extent, visible during the electoral campaign and confirmed in the results, let alone the rise of extremist measures among young voters and their political support. The aim of the research paper is to confront the research data in Slovakia from two contrasting field sites with the electoral paradigms as interpreted from the electoral results and support for particular political parties and movements. We argue using the combined methodological approaches from quantitative surveys and in-depth individual interviews with young people from MYPLACE project and other research data to compare the research implications with the electoral results and related major themes.
\end{abstract}

KEY WORDS: elections, far-right parties, MYPLACE, extremism, youth

\section{INTRODUCTION}

This article aims to contribute to the discussion related to the changing electoral scenarios and the electoral results from the national perspective and the implications measured through international collaborative research project MYPLACE that indicated in Slovakia the continuous turnover of especially young citizens and voters to standard political parties, trust in political institutions and leaders as well as the open support for alternative, radical and extremist political visions. Based on this narration, we aim to structure the paper to interpret the research data and main research domains and attributes to deliver the dependence of the research results with the electoral data and compare them. From this reason, we will operate the qualitative as well as quantitative data as emerged from large-scale survey in Slovakia in 2012 with young respondents. The other part of data analysis contains the results from the follow-up in-depth

\footnotetext{
${ }^{1}$ PhDr. Jaroslav Mihálik, PhD., asisstant professor and researcher, University of Ss. Cyril and Methodius in Trnava, Faculty of Social Sciences; post-doctoral research fellow Charles University in Prague, Faculty of Social Sciences. email: jaroslav.mihalik@ucm.sk
} 
interviews with young respondents in 2012-2013 from the research sample. The sample consisted 1200 participants in the survey questionnaire in two contrasting research sites in Slovakia: Trnava and Rimavská Sobota. The interviews were done with 60 interviewees, 30 from each field site in Slovakia. The major aim is to interpret and compare the research data with the electoral results in parliamentary elections in Slovakia and associated topics and themes as emerged from the public and media discussion.

\section{RESEARCH PARAMETRES}

MYPLACE was a major 7.9 Million Euro EC funded project, running from June 2011 to May 2015 which explored young people's civic, political and social participation in 14 European countries, and particularly how it is shaped by the past, present and future shadows of totalitarianism and populism in Europe.

Conceptually, it goes beyond the comparison of discrete national 'political cultures' or rigid classifications of political heritage, such as 'post-communist' or 'liberal democratic'. It is premised rather on the pan-European nature of a range of radical and populist political traditions and the cyclical rather than novel nature of the popularity they might currently enjoy.

Empirically, MYPLACE employs an impressive combination of survey, interview and ethnographic research methods to provide new, pan-European data that not only measures levels of participation but captures the meanings young people attach to it.

Analytically, through its specific focus on 'youth' and the historical and cultural contextualization of young people's social and political participation, MYPLACE replaces the routine, and often abstract assumptions of presumed 'disengagement' from politics with an empirically rich mapping of their understandings and orientations towards European civic and political spaces.

In policy terms, MYPLACE identifies both the obstacles and facilitators for young people's reclamation of the European political arena as 'my place'.

MYPLACE was distinctive in taking a multi-methods approach, including large scale survey, in-depth interviews and ethnographic case studies to inform policy and practice in holistic ways. Rather than seek to generalise in spurious ways about countries as a whole, the historical memory (WP2), survey (WP4) and in-depth interview research (WP5) was conducted at two contrasting sites in each country in order to show the interactions between local, national and international influences on young people's attitudes and behaviour. This facilitates deeper, more holistic understanding of the contexts shaping young people's attitudes and behaviours, as a basis for more effective policy responses and interventions. Project teams have worked closely with policy partners 
through Youth Policy Advisory Groups (YPAGs) to design and realise the research, and advise on its implications.

On the one hand, there is the town of Trnava with a homogenous ethnic structure and a relatively low level of social and economic deprivations. The location ranks among "strongly developing" areas, mainly considering the economic aspect. Its strong side is the proximity of the capital and the PSA Peugeot automobile plant. Several universities are located here - therefore, the population of youth concentrates here. Trnava hosts multiple generations of Roma travelers from other regions who came to the city during the 1980s and 1990s. Relations between the communities have suffered as a result of reports of a substantial crime rate among the Roma population of the city. There is also evidence of the potential rise of neo-Nazism, anti-Semitism and intolerance in Trnava associated with ultras and hooligans of the local football fan club of Spartak Trnava.

On the other hand, there is the district of Rimavská Sobota, which is characterized by a high ethnic heterogeneity rate as well as, considering the Slovak conditions, an above-the-average level of social and economic deprivations. In this location several ethnic groups meet - Slovak, Hungarian, and Romany. The area ranks among the poorest locations in the country (high unemployment and poverty rate, social issues). The problems have been cumulating there for several decades and are mainly connected with economic opportunities of the whole region. The research was conducted at the end of 2012 and early 2013. 


\section{THE YOUTH PERSPECTIVE: DEMOCRATIC GOVERNANCE AND CIVIC ENGAGEMENT}

There are some important aspects regarding the nature of the welfare regime in Slovakia. As observed by Jolanta Aidukaite (2011) the post-communist countries still struggle to catch-up with the western democracies in the field of established welfare systems even after the great changes and reforms in financial sphere, GDP growth over 20 years of economic transition from centrally planned to market one. It is obvious that the social indicators such as minimum wage, expenditures on social protection, life happiness, and poverty, inequality in income, unemployment and mortality pointed on the level of development in the Central Eastern Europe and show the differences. With this in mind where do we associate Slovakia as a representative of the former Soviet republic? Esping and Andersen (1990) identified three different types of welfare regimes: liberal, corporatist, social - democratic. Post-communist countries are often considered to be "hybrid regimes incorporating attributes of all categories discussed." The events and system transformation together with democratic consolidation in these countries cannot be limited to only one out of the three regimes. Noemi Lendvai (2008) pointed on Slovakia, Estonia, Latvia and Lithuania as the countries with neoliberal regime from the perspective of low social expenditures.

Regarding the relationship between the center and regions in Slovakia, regional differences are present here. Research has shown that the strengthening of regions would be necessary to minimize the role of government. According to Dušan Sloboda the regional differences are not the biggest problem in Slovakia, but it is the lower income levels than the old EU member states from a long time perspective.

EU membership is an important factor influencing the nature and direction of social policy in Slovakia. The development of social policy in Slovakia can also be characterized as an attempt to "fit and exploit the opportunities offered by the EU institutions and regulations" (Kusá and Gerbery, 2007). Since 2006, the Open method of coordination within the EU is applied and its role is to facilitate greater social cohesion within the EU. Slovakia used this space to implement social and economic reforms.

Jolanta Aidukaite (2011) also argues that the economic crisis of 2007-2009 hit harder the CEE countries than their western counterparts, and this fact has had a negative impact on social indicators of these countries. Ubiquitous and daily witnessed crisis is also one of the factors that influence the form of social system in Slovakia.

The European Union and Slovakia are currently facing unprecedented demographic changes. Trends of the pan-European character point out the 
population decline and population aging. These trends in the coming decades will gather significant influence in shaping the welfare system. After 2025, we expect a decline in population and the process of aging is irreversible which would not stop earlier than in 2060, but the population will be already about 10 years older than at present. It is likely that in 2050 the population of Slovakia is less numerous, and probably more ethnically diverse. Ageing will have a very strong impact on social development. Inevitably it will be necessary to reform the labor market, social security, education and health. Also, other areas of functioning of the society such as housing, transport, services will have to adapt to changing conditions. The aging process will negatively affect the working and productive groups of citizens (Aidukaite, 2011).

The current economic crisis is having a negative impact on the position and interests of young people in Slovakia, especially in terms of their employment. After a period of economic growth, there was a period of decline, which is particularly negative impact on employment. Young people and especially recent graduates are now applied to problems in the labor market. Michal Palenik gives several reasons for youth unemployment: the crisis that caused the downturn in job creation, population growth which creates enormous pressure not only on the situation in terms of employment, but also for pensions and so on, the educational system (the ever-increasing number of university-educated people, which creates a high percentage of unemployment rate among people with the lowest education) as well as labor law. The share of permanent contracts in Slovakia in 2011 was 7\%, which is half of the EU average. Among young people, this percentage was higher (17.8\%), but also what is just under half the EU average.

According to available data the proportion of young people (age group 0-30) in the population of the Slovak Republic due to 31.12.2009 was 40.68\% (Správa o mládeži, 2010). The proportion of youth aged 16-25 was $37.60 \%$. Demographic trends in Slovakia are influenced by many factors (geographic location, industrial, urban versus rural areas, suburban areas versus those isolated). Youth is the most sensitive social group that is significantly affected by changes in society. This is reflected for example in lifestyle; youth has a special and different value system and new forms of partnership - later marriages, increase in the number of young people living in partnership, not marriage (Správa o mládeži, 2010).

Youth in Slovakia is perceived as a carrier of changes. Youth helped to topple the totalitarian regime in 1989. It is active as a social force and ceased to be a passive object of the totalitarian policies of the Czechoslovak state (Macháček, 2003).

Participation of young people in Slovakia is visible in many areas of life and we can see the various specific examples. Generally speaking, the active participation of young people in public life and public decision making in 
Slovakia is reflected in numerous areas from the national to the regional level, based on legislative assumptions - Constitution, Law on Municipalities, Administrative Procedure Act, the Freedom access to Information Act, the state administration in education and school self-government and so on (Pauliniová, 2009).

It is possible to observe some regional differences - young people in western Slovakia have increased interest in the policy-making at local and regional level, in eastern Slovakia, the knowledge of the functionality of public policy and related political issues is significantly lower. It is also necessary to mention the issue of not -participation as a form of protest, as the communist regime in 1989 in Czechoslovakia advocated quite different forms of participation - compulsory participation but passive (Macháček, 2012).

According to the WP3 report young people do not very incline to membership in civic or political organizations. They rather incline to activities and organizations involved in sport, culture or religion. We can say that young people are most interested in topics that are directly relevant to their lives (Macháček, Štefančík and Horváth, 2011).

At the national level, there are several organizations that are either directly part of the Ministry of Education, or cooperate with state institutions in youth policies. These are as follows: IUVENTA - Slovak Youth Institute, RMS Youth Council of Slovakia, Intenda Foundation, Research Institute of Child Psychology and Patopsychology. At the regional level there is the regional branch of the Youth Council, and variety of leisure centers in different cities. Electoral participation of young people in Slovakia can be characterized by the statement: "Young people are not interested in politics" (Mihálik, Podoláková and Štefančík, 2010). Young people are also after obtaining the right to vote not participating in the electoral process in such number as would be expected. Classic problem is not only first time voters and their participation in elections, but in general youth participation after they are eligible to cast the votes (Macháček, 2008). Young people do not participate in elections because they have little information, but paradoxically are not trying to get this information on their own. Slovakia also talks about the paradox in which young people have relatively high confidence in EU institutions, but nevertheless the European Parliament elections turnout is among the lowest records. This paradox among first time voters was not confirmed by the voting behavior research pursued by the research team at Ss. Cyril and Methodius University in Trnava. Participation in the form of protest among Slovak young people is present, but not anywhere as much as in France. Recent expressions of dissatisfaction within (not only) young people came before early parliamentary elections in March 2012, when disgruntled citizens protested and called for investigation of corruption cases Gorilla, which is associated with top political leaders. 
The trust of young people in political institutions and their leaders in Slovakia, according to research (Macháček, 2008) is rather low. This observation is particularly valid for the national parliament and politicians and policy at the national level. The publication The Civic Deficit of Youth from research conducted between 2005 and 2007 among students in Slovakia shows that young people do not trust politicians, political parties, the Government or the National Council. In all cases the level of trust ranged from 39\% to 59\% (Macháček, 2008). For most young people in Slovakia policy is synonymous with corruption and empty promises. Cases like the above-mentioned Gorilla and their (dis) solution of the competent authorities helped to preserve such negative perception. In Slovakia, a relatively strong position holds the organization of the Catholic Church, as most of the population professes the Catholic faith. The only national level institution that usually gets relevant trust is the President. The rate of high popularity is perceived already at the time of its creation in 1993. Since that, most of the people, including youth trust the head of the state. We can explain it that the institution of the president plays huge civic role in the politics, regardless of who is currently the president.

The young people usually attend planned events, boycotts and campaigns which are organized by the youth associations, mostly the associations bound with the political parties such as Christian Democratic Youth of Slovakia, Civic Democratic Youth, and Young Social Democrats. Their activities are usually sponsored and managed in order to support the particular political organization. There are also several Christian associations subdivided into confessions - these are sponsored by the Church and donation mechanisms, or alternatively through gifts or own budget.

There are number of youth subcultures, but only some of them will get to interact with political extremism. In fact, we cannot say that the whole subcultures are extremist because they are affected only partially. Other parts of subcultures can be apolitical, or move the boundaries of democratic politics. Each of the subcultures extremism can affect in different directions i.e. that of a particular subculture can be found as the right-wing and left-wing extremist variants. Among the various subcultural factions there might be a struggle for dominancy. In addition, there are hostilities among the subcultures - punk vs neo-Nazi, for instance. The creation of ideas and the image of the subcultures is also involved through ordinary media not only specialized "zines," music or underground society. Even it may happen that the false information about the development of subcultures abroad, published in Youth magazine temporarily affects the behavior of the subculture in Slovakia. A large proportion of youth do not belong to any of extremist subculture identity. Young people are organized in the various extremist political interest groups, including illegal militant and paramilitary organizations groups, youth organizations of political 
extremist parties (Peoples' Party - Our Slovakia) or in nationalist political parties themselves - such as the case of Slovak National Party prior to its leadership transformation.

In Slovakia, the interest of youth involvement in youth organizations is relatively low, despite the existence of a large number of youth organizations. This lack of interest or reluctance may stem from the past era of totalitarian organization, where membership was required in the mass organizations. The current crisis of association, however, derives not only in the past, but it is also a remark of self-esteem in the system of opportunism. Your paper should be written in English language in the same format as this file.

\section{THE OPENNESS AND CONTINOUS PROPENSITY TO FAR-RIGHT POLITICS}

Many research studies in Slovakia point on the current openness of society to support the far-right politics and politicians. The research implications from 2013 project KOMPRAX The openness of young and older generations in Slovakia toward radical-extremist and nationalist movements authored by Ladislav Macháček (2013) demonstrate that supporters and sympathizers of Slovak extremists count at least 2000 people, while hundreds of them could be considered as radical and dangerous. In reality, the structure and basis of radicals is rather wider as identified through the electoral success of the newly established political platform of Peoples' Party - Our Slovakia (PPOS) already in 2010 and 2012. In both elections, the party continuously gained around 40000 votes. While in the 2010 parliamentary elections, the party acquired only $1,33 \%$ of votes (33 724 votes in total), in early parliamentary elections the results was marginally higher $-1,58 \%$ votes (40 460 in total). According to then analyses, PPOS keeps doing target oriented campaign to motivate those voters who are negatively oriented to Roma population and live in the very close neighbourhood to Roma settlements and regions affected by the problematic behaviour of Roma (Kluknavská, 2012, p. 30). The empirical data from the KOMPRAX project provide narrow and interpretative dimensions and indicators as interpreted by the respondents. These results confirm the implications from the data analyses of the MYPLACE project which has confirmed the very similar trends among young respondents. According to Nociar (2012) right-wing extremism in Slovakia can be distinguished in two kinds of entities: groups of skinheads and leaderless resistance groups operating unofficially, independent of political parties without a stable organizational structure; and civic organizations and political parties that try to establish permanent structures of institutionalized right-wing extremism. The best known and most successful of the latter type are Slovak Unity (Slovenská Pospolitost') and People's Party - Our Slovakia 
(Ludová strana - Naše Slovensko). The latter one confirms the successful political transformation of the banned Slovak Unity into the effective and electorally successful political party with the same leadership but more organized nature within the legislative framework which makes it tolerant in the society. Nociar goes on to note that, in Slovakia, right-wing extremism emerged directly after the demise of the communist regime in 1989. While in the 1990s, members of the skinhead subculture were the most typical holders of right-wing extremist ideas, since 2003, a crucial change in representation has occurred, and right-wing extremism in Slovakia has become more organised and has developed political aspirations. This is one of the reasons for the organisational diversity of right-wing extremist groups, which operate as:

- political parties;

- civic associations;

- unofficial groups (subcultures or leaderless resistance groups).

Most often, the concept of right-wing extremism is associated with violent demonstrations against people of a different race or ethnicity, or people who are otherwise different. People are often associated with right-wing extremism for denying the democratic functioning of society and its institutions although as an ideology right-wing extremism is not perceived to explicitly deny democratic principles. Moreover right-wing extremists might be individuals or groups that seek violence or ideologist not directly engaged in violence but who promote the principle of inequality of different races and ethnicities (often rooted in an ideology of fascism and tradition of the Slovak state during World War II).

As Nociar (2012) observes, in terms of ideology, extremist groups in Slovakia have two main profiles:

- the ultra-nationalist stream - who espouse nationalism, anti-Semitism and anti-Hungarian chauvinism and are apologists for the wartime Slovak State and draw on its legacy;

- the neo-Nazi stream - who are typically racist, anti-Semitic and apologists for the Third Reich.

Surprising radical increase was measured in the very recent parliamentary elections in March 2016 when the party of Marian Kotleba received a historical record of $8,04 \%$ votes which equals to 209779 total votes gaining 14 mandates in 150 seat parliament. The continuous support for the alternative parties might be interpreted as the failure of traditional parties to deliver prompt solutions to the economic and social issues that are not solved systematically over the decades and especially, the young voters who have been born and raised in the democratic transition period are most prone to support the different political platforms, usually oscillating between democratic standards and extreme variations of the political spectrum. Such is the case of Kotleba's party that had transformed from the previously banned civic organization and political party 
into successful political alternative indoctrinating the ability to promptly react and reflect the society needs and providing radical solutions. The table below illustrates the share of reasons why people voted for Kotleba's People's Party Our Slovakia.

Table 1: Dimensions and indicators of radicalism and extremism from KOMPRAX project (761 respondents)

\begin{tabular}{|c|c|}
\hline \multirow{2}{*}{ Antisemitism } & Jews are strange and weird, they do not fit to us. \\
\hline & Jews have too much influence over the economy and our state. \\
\hline \multirow[t]{2}{*}{ Racism } & $\begin{array}{l}\text { The lives of some nations and ethnic groups are less valuable } \\
\text { due to their different civilization and mentality. }\end{array}$ \\
\hline & $\begin{array}{l}\text { Similar to life in nature also in human kind the fittest from } \\
\text { nation should rule the less fit. }\end{array}$ \\
\hline \multirow[t]{2}{*}{ Homophobia } & $\begin{array}{l}\text { Homosexuals are dangerous for the future of the nation and they } \\
\text { have no place in our society. }\end{array}$ \\
\hline & $\begin{array}{l}\text { Homosexually oriented people should not be representing the } \\
\text { public functions or working with youth, such as teachers. }\end{array}$ \\
\hline \multirow[t]{2}{*}{ Anti-gypsism } & $\begin{array}{l}\text { Police and courts should be stricter to Roma than to other } \\
\text { people. }\end{array}$ \\
\hline & $\begin{array}{l}\text { Roma that do not work and do not seek requalification should } \\
\text { lose the right for social support. Other (non-Roma) people } \\
\text { should not be affected. }\end{array}$ \\
\hline \multirow[t]{2}{*}{ Nationalism } & $\begin{array}{l}\text { High state positions should be represented only by Slovak born } \\
\text { people. }\end{array}$ \\
\hline & The interests of Slovakia should be superior to the EU interests. \\
\hline \multirow[t]{2}{*}{ Authoritarianism } & $\begin{array}{l}\text { There should be a strong leading personality in Slovakia, ruling } \\
\text { strict and with respect to everybody's interests. }\end{array}$ \\
\hline & $\begin{array}{l}\text { It would be better to have one person to decide than many } \\
\text { politicians solving the problems. }\end{array}$ \\
\hline \multirow[t]{2}{*}{ Collectivism } & $\begin{array}{l}\text { If the interest and demands of an individual get in conflict with } \\
\text { the interests of the group or nationa, the individual should } \\
\text { submit to it. }\end{array}$ \\
\hline & $\begin{array}{l}\text { The nation is superior and in the case of emergency an } \\
\text { individual has to sacrifice his needs. }\end{array}$ \\
\hline \multirow[t]{2}{*}{$\begin{array}{l}\text { Anti-Hungarian } \\
\text { position }\end{array}$} & $\begin{array}{l}\text { Hungarian nationals in Slovakia should speak exclusively } \\
\text { Slovak language in public places and institutions. }\end{array}$ \\
\hline & $\begin{array}{l}\text { Hungarian nationals in Slovakia who have lately acquired } \\
\text { Hungarian citizenship should be deprived of the Slovak one. }\end{array}$ \\
\hline
\end{tabular}

Source: Macháček, 2013 
Table 2: Reasons of voting for Kotleba - Peoples' Party - Our Slovakia

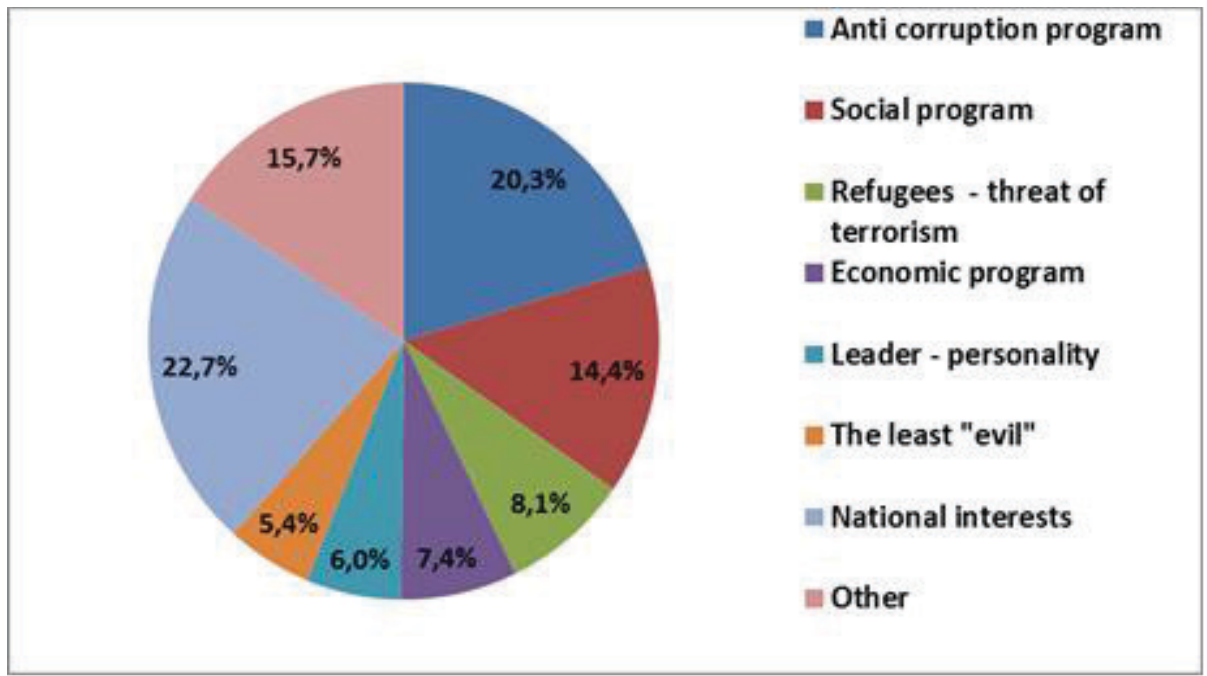

Source: Exit poll FOCUS Agency for TV Markíza

In addition to the variety of reasons of the party electoral support we may argue that almost $23 \%$ of young people, usually first-time voters have voted for the party. This has been already identified in the pre-election surveys that young people are prone to give vote either to Kotleba's party or, secondly to the newly emerged populist movement of a business man Boris Kollár representing the party Sme rodina (We are family). The Slovak parliamentary elections have confirmed the growing and continuous trend of political support and success of new and alternative political parties that usually emerge just prior to the election itself. We may also demonstrate that the support for the new and alternative parties is typical for young people, stratified among various social categories such as employed, unemployed, university and secondary schools students but also citizens already having college degree which implies that it may not be just a protest voting but more likely the issue of an angry voters which political, social and economic demands were not fulfilled during the previous parliamentary structure. In case of young people, we have already proven in the previous international collaborative projects such as MYPLACE (Memory, Youth, Political Legacy and Civic Engagement) that Slovak youth is mostly prone to openly speak about racism, unresolved issues related to the social and economic deprivation in regions and their openness to support the alternative, radical and extremist leaders and parties. Quite surprisingly, these arguments are 
valid not only for the exposed regions and economically deprived localities, but according to the project respondents, more generally in nation-wide context.

\section{ELECTORAL RESULTS AND RESEARCH IMPLICATIONS: SYNERGIES AND ANALYSES}

The spring elections in Slovakia have brought several topics for discussion. First of all, the results pointed on the weaknesses of the traditional political parties that have established in Slovakia throughout it short period of independence. Secondly and, perhaps most importantly the electoral process and the results have brought new political parties into the parliament, especially the party of Marian Kotleba Peoples' Party - Our Slovakia that has been ever since its establishment subject of many academic and public discussions. Another topic resulting from the parliamentary elections is the rise of negative campaign, antiEU rhetoric of political leaders but also radicalization and extremism among voters. These issues are inevitably bound with the changing nature and moods of the Slovak voters, the political processes and social and economic deprivation in various regions as well as tight international relations escalated through the very recent refugees' crisis and migrants' influx to Europe. The spread of fear, paranoia, and national securitization campaigns as well as the negative campaign have all mobilized the voters to stress the position of nation state in Europe and to support, sometimes, non-democratic policy making, more authoritarian approach and rather populist and antagonistic approach to democratic values. It may be true that in case of Marian Kotleba party they have reevaluated their position from the formerly banned civic organization with clear neo-nazi orientation towards more tolerable agenda of fighting the social and economic depression, anti-elite rhetoric and anti-EU position enabling the party to be recognized as already standardized model of new political waves that is currently present all over the Europe. It implies that the model of governing and problem solution of the conventional political platforms has reached its bottom, together with the responsiveness to ordinary people and conflict resolution. Nowadays, the major enemy focus is not the bilateral conflict among Slovaks and Hungarians, but more specifically the internal problems of the citizens, such as lack of employment options, low salaries in deprived regions where Kotleba has gained the most political support. Also target oriented campaign in such regions together with the impact of the social networks have played major role in the electoral success. 
Scheme 1: Young voters' share of popular votes to political parties in 2016

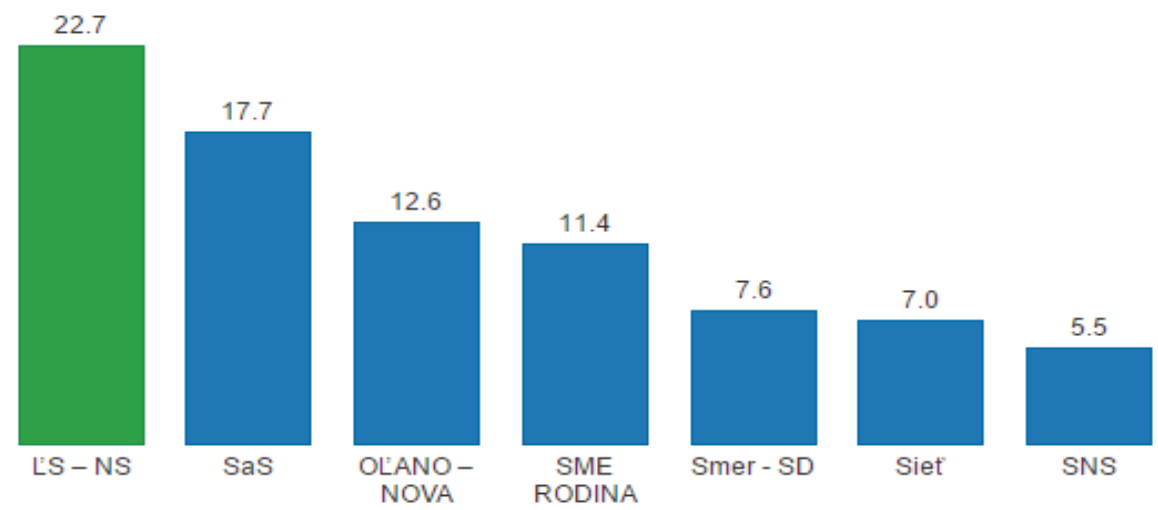

Source: Exit poll FOCUS Agency for TV Markiza

From the perspective of the MYPLACE project one of the main tasks and indications were to explore the openness and receptivity of young people to extremist and populist political leaders, ideologies as well as political agenda among the target group of young individuals. In MYPLACE project we operated term extremism in multiple dimensions, most specifically as a generalized measure of deviance from the political normative, i.e. anti-democratic approach and the European-wide context of culture and democratic values. We explored extremism as a concept that goes beyond the traditional normative political procedures defined by democratic process itself with clear-cut oppression of opposition and intolerance. We distinguished the concept of extremism from radicalism, referring to major difference of anti-democratic approach of extremist ideology, compared to radicalism which is more tolerant to democratic standards and does not openly stand on the opposite to democratic establishment. Although, there are many ideologies that call to diminish the democratic nature and perspective in order to realize the ideological aims within the society and power demand. Traditionally, we may stem from Cas Mudde articulation of revolutionary perspective of radicalism which claims to be leftist compared to right wing radicalism which is considered to be reactionary (Mudde, 2007, pp. 25-30). While the leftist-socialist approach is aimed to resource redistribution and creation of strong socialist anti-capitalist state, the latter one points to restore an earlier order. Radicalism has become more wide-spread among many particular groups and institutions creating the multipolar society. Concept of radicalism is mostly attached to populist left and right wing political parties and movements that have increasingly gained new political positions in nation states and are electorally successful. From this perspective, these movements and parties distinct from extremist parties since they remain democratic from their 
nature while opposing some fundamental statuses in the society, orienting to values of liberal democracy and promoting the intolerant approach including the notions of nativism, authoritarianism and populism (Mudde, 2007).

In this section, we use the statements and quotations from the in-depth interviews with MYPLACE respondents in two field sites - Trnava and Rimavská Sobota to demonstrate the patterns of support or denial of extreme right in Slovakia which ultimately gives a better view over the electoral results from the 2016 parliamentary elections, especially among young people. The major research implication and suggestion contained vision that support for farright parties as well as radical ideologies was represented by the minority of respondents. The research results have not confirmed such hypothesis and explored more genuine sympathies and propensity to extremist ideas and their support. One of the most visible features of support to such ideas is demonstrated by broader ideological perspective. Tomáš from Rimavská Sobota notes that "I agree with some of the Hitler's ideas" while other respondent, Libor from Trnava, claims that "extremists focus and address the most urgent problems of current society." To keep in mind the growing and urging problems the respondents associate these mostly with ethnic conflict, immigration from third countries and possible dangers implying from different religions, such as Islam and Jewish religion. For example, in Slovak perspective the most vivid section of ethnic conflict was at the time of research (2012-2013) identified as the Roma problem and from national point of view, the issues to do with Hungarians living in Slovakia. Kristína from Rimavská Sobota states that "I do not want any of the Hungarian parties ruling in Slovakia, simply because it is our country." On the contrary, the ethnic cleavage related to Roma population is depicted by not working and receiving money for nothing perspective: "they get 500 or $400 €$ every month without doing anything, they sit at home, have 4 or more kids and they use to live from our taxes" (Marek, Rimavská Sobota). Increased criminality in regions and more security and safety issues are also aggregated to Roma: "I think they cause criminality in the regions and there are too many Roma people and we need to be aware of this. I fear for my life when I go home at night, because they do not think about consequences of their acting, they do not think rationally" (Krasko, Rimavská Sobota). It is thus confirmed that targeted campaign in the marginalized and deprived regions have shown higher support for radical right and extremist parties such as the one led by Kotleba. Usually, young respondents claim they have some sympathies with such radical problem solutions advocated by the party and its leaders. On the other hand, the direct engagement with extremism is often supplemented with doubts about the capacity of extremist party to find appropriate way to solve the problems. For example, Lena from Trnava claims: "I had sympathies with Kotleba's party because it was something different, maybe more radical but it would need to 
have something more to offer rather than promises." Another respondent from Trnava, Dušan, notes that "Kotleba is perhaps the only one trying to do something about the Roma question, he has some ideas but .... It is not enough."

There is a society-wide and also political argument that a typical voter for extremist party is a young un-educated and unemployed male which also belong to a stereotype often used by the political elites. Jovo Bakić also points on this stereotype that a typical extreme-right voter is categorized to be twenty five-year old unemployed man, with below-average education (Bakić, 2009). The exit polls and pre-electoral as well as post-electoral research indicate that usually young people (18-25) seek to support the alternative political parties and leaders, but the sociological survey also explored that most of them have either secondary school and every fifth voter of Kotleba had gained university degree. Most of them are also in the working status. The stereotype of uneducated, non-intelligent and working class individual voting for extremists is thus slightly denied. On a contrary, those who support extremist movements are according to our respondents limited by their own intellectual potential to favor extremists: "I do not think an extremist party can solve anything. Like Jobbik in Hungary. I do not really understand how an intelligent person can vote for something like that" (Libor, Trnava).

Then, the phenomenon of extremism in Slovakia is multiplied by the open demonstrations to notions of racism and nativism. These attributes are often expressed openly by the respondents who agree that racism is wide-spread across the country and society: "everyone is against Roma. We are racist country. I know only few people that do not have issues with Roma population" (Jana, Trnava). The legal position of extremist movements in Slovakia should not be a matter of ban or censorship, the phenomenon is spread among MYPLACE respondents. Although, Marian Kotleba attracted significance domestically and internationally mostly by describing him as neo-nazi and authoritarian personality "he might have some good ideas, but maybe only faking. I could not trust this person" (Barbora, Rimavská Sobota). Such vision and the question on limits to extremism, there are no alternatives for young people, although they claim that extremism is not an appropriate form: "I do not support radical solutions because it is not like conflicts should be solved. I do not know any better solution right now, though. But I do not support extremists" (Vladimír, Trnava). A ban on extremist political parties is not necessary: "They should not be banned, of course. They cause no harm to anyone. It is democratic, you should also let radicals to express their feelings" (Ivan, Trnava). Then, there is an appeal of a hidden support or not expressed support for extremists owing to the stigmatization and media presentation of extremism and radicalism and young people tend to resist to be labelled as extremist. So there is a kind of passive support to extremism, which, according to the research and electoral results 
might have played a huge role in the distribution of votes either to Kotleba or other populist parties.

\section{CONCLUSION}

As interpreted in the previous parts we have put forward the question of matching the electoral paradigm with the international and domestic research results that indicated the continuous support and propensity of Slovak voters, especially young people towards the far-right political parties, leaders and political agenda. Considering the young generation of voters in Slovakia, we have confirmed the interrelation between the research results and implications with the reality of the electoral process and results. There are several factors that have influenced the process: the potential of young voters in Slovakia aged 18-25 that makes a potential of 200000 votes amongst the first-time voters who share different visions and patterns of political engagement compared to their counterparts or older generations. Secondly, the research results indicated the mainstream political parties on decline compared to new wave populist and radical movements promising the prompt and proper solutions to problems mostly visible in the socially and economically deprived regions in Slovakia but also beyond such regional borders. The anti-establishment, anti-EU and anti-elite discourse among people in Slovakia is continuously growing and creating a new cleavage among voters. Ultimately, there is a shift in political leadership such as in case of Marian Kotleba party with target oriented campaign and systematic strategies in building their voters' capital. We have confirmed that mostly young people in Slovakia are prone to support the new, alternative, populist and often extremist views of political leaders that urge to fight corruption and have antisystemic efforts. Then, the conclusion aims to incorporate the concept of lost legitimacy to the elections as well as the different levels of trust to democratic values and political institutions. The research and electoral results have confirmed that young people shall be equipped with knowledge and more insights into politics which results in effective participation in formal and nonformal politics and civic engagement. The MYPLACE interviews in both research locations in Slovakia have confirmed the general sources of rise of the extremism in contemporary Slovak society to be: poverty and lack of social inclusion; tension escalated by incorrect and unverified information from some media; the role of family and community in shaping the views of youth. Young voters share the view that the political system and order serves only older people and rich ones, putting the system more towards into oligarchy. From these reasons, we observe the growing neglect and youth disconnection from politics which is substituted by the protest movements which may, to some extent, 
deteriorate civic participation and undermine the already fragile faith in democracy.

\section{REFERENCES}

Aidukaite, J., 2011. Welfare reforms and socio-economic trends in the 10 new EU member states of Central and Eastern Europe. Communist and Post-Communist Studies, 44(3), pp. 211-219.

Bakić, J., 2009. Extreme-Right Ideology, Practice and Supporters: Case Study of the Serbian Radical Party. Journal of Contemporary European Studies, 17(2), pp. 193-207.

Esping-Andersen, A., 1990. The Three Worlds of Welfare Capitalism. Cambridge: Polity.

Kluknavská, A., 2012. Krajne pravicové strany v parlamentných vol'bách 2012 na Slovensku. Rexter - časopis pro výzkum radikalismu, extremismu a terorismu, 10(1), pp. 1-35. [online] Available at: https://www.ceeol.com/search/article-detail?id=106849 [Accessed April 15, 2016].

Kusá, Z. and Gerbery, D., 2007. Europeanization of Slovak social policy. Streamline „The Lisbon Process and its Social Policy Reforms in the Member States" Social Policy in Europe: Changing Paradigms in an Enlarging Europe? ESPAnet Conference 2007, 20-22 September 2007, Vienna. [online]

Available at:

http://eucenter.wisc.edu/omc/new\%20omc\%20links/01_gerbery_daniel.pdf [Accessed April 15, 2016].

Lendvai, N., 2008. Incongruities, paradoxes, and varieties: Europeanization of welfare in the new member states. Paper Presented at the ESPAnet Conference, 18-20 September 2008, Helsinki.

Macháček, L., 2003. Generačný problém ako spoločný problém generácií. BratislavaTrnava: Slovenská sociologická spoločnost' pri SAV.

Macháček, L., 2008. Občiansky deficit mládeže: Politická a občianska participácia študentov na Slovensku. Bratislava: Slovenská spoločnost’ pre výskum mládeže IUVENTA. [online]

Available at:

http://www.iuventa.sk/files/documents/7_vyskummladeze/publikacie/obc.deficit.mlade ze.pdf [Accessed April 15, 2016].

Macháček, L., 2012. Slovenská mládež v zrkadle sociologických výskumov po roku 1993. Bratislava: Slovenská sociologická spoločnost' pri SAV. [online] Available at: https://www.iuventa.sk/files/publ_slovenska_mladez_v_zrkadle_vyskumov.pdf [Accessed April 15, 2016].

Macháček, L., 2013. Otvorenost' mladšej a staršej generácie Slovenska k radikálnoextrémistickým a nacionalistickým hnutiam. Bratislava: Komprax Iuventa.

Macháček, L., Štefančík, R. and Horváth, P., 2011. Country based report on focus groups and expert interviews (SLOVAKIA), MYPLACE project deliverable. 
Mihálik, J., Podoláková, E. and Štefančík, R., 2010. Prvovoliči a ich voličské správanie. Výskum politickej participácie mladých l'udí. Bratislava: Iuventa. [online] Available at:

http://www.iuventa.sk/files/documents/7_vyskummladeze/spravy/davm029/ucm_prvov olici.pdf [Accessed April 15, 2016].

Mudde, C., 2007. Populist Radical Right Parties in Europe. Cambridge: Cambridge University Press.

Nociar, T., 2012. Right-wing extremism in Slovakia. International Policy Analysis, Friedrich Ebert Stiftung. [online] Available at: http://library.fes.de/pdf-files/idmoe/09567.pdf [Accessed April 15, 2016].

Palenik, M., 2012. Youth Unemployment in Slovakia. London: Social Europe, June 11, 2012. [online]

Available at: https:/www.socialeurope.eu/2012/06/youth-unemployment-in-slovakia/ [Accessed April 15, 2016].

Pauliniová, Z., 2009. Participácia mládeže na Slovensku. [online]

Available at:

http://www.rmpk.sk/mladeznicka_politika_a_participacia/Participacia_mladeze_na_Sl ovensku.pdf [Accessed April 15, 2016].

Sloboda, D., 2006. Slovensko a regionálne rozdiely Teórie, regióny, indikátory, metódy. Bratislava: Konzervatívny inštitút M.R. Štefánika.

Správa o mládeži, 2010. Národná správa o štátnej politike vo vzt’ahu k det’om a mládeži v Slovenskej republike. Bratislava: Ministerstvo školstva Slovenskej republiky. [online] Available at: http://www.iuventa.sk/files/sprava_omladezi2010_final.pdf

[Accessed April 15, 2016]. 